\title{
Raro. \\ Una historia gay de Chile, de Óscar Contardo
}

\author{
Gonzalo Andrés Salazar \\ Universidad de Chile \\ desterritorializado@gmail.com
}

El periodista Óscar Contardo es nuevamente éxito de ventas con la publicación de su tercer libro, Raro. El autor de Siútico vuelve a la carga, esta vez, con la provocativa misión de elaborar una historia gay de Chile. Pero, ¿qué entiende el autor por historia gay? En la introducción a su texto, señala que su contenido es la "forma en que los varones que se inclinan por personas de su propio sexo han sido tratadas en distintas épocas: sodomita, maricón, invertido, homosexual, gay" (11). Su interés, entonces, es hacer una historia de la evolución de los comportamientos de una mayoría, la que discrimina a los homosexuales. Es decir, expondrá los prejuicios que históricamente han rodeado la homosexualidad, para refutarlos y evidenciar, bajo éstos, una voluntad políticamente in- teresada, inscrita a su vez en un régimen específico de poder. La metodología usual del texto es el análisis de discurso.

En ocho capítulos y 402 páginas, Contardo narra diferentes relatos entretejidos en torno a los prejuicios e ideas que han rodeado la homosexualidad. Escribe sobre la formación de estos discursos en la Baja Edad Media, su migración hacia tierras americanas y su importancia en la conformación de la identidad nacional. También aborda su mutación en un discurso eugenésico e higienista (biopolítico) y las prácticas de cierta bohemia santiaguina en relación con dichos discursos. Asimismo, evidencia la homofobia de la Unidad Popular y de la dictadura militar por igual, y el surgimiento de una vida nocturna gay en este último período, 
junto con la epidemia del sida. Quedan también al descubierto las cuentas pendientes de nuestra menguada democracia en materia de derechos civiles para personas LGBT.

Claramente un best seller dirigido a un público masivo, el libro ansía tener también un fin pedagógico: educar a el/ la lector/a sobre la homosexualidad. Para tales efectos, Contardo vuelve una y otra vez sobre los "estudios más exhaustivos y científicos" (30) con el fin de desligar, por ejemplo, la asociación entre homosexualidad y pedofilia. Con estas y otras estrategias, desea situar a la homosexualidad como una opción o condición "diferente", alejándola de conductas consideradas aberrantes.

Las fuentes que informan el texto consisten en archivos judiciales, periódicos, entrevistas y la producción literaria y cultural en general. Añade, de este modo, cierta metodología historiográfica a las técnicas periodísticas. Sin embargo, esto no redunda en un libro propiamente historiográfico. Su intención no es serlo, está claro, pero aún así, me parece productivo marcar la distancia entre esta "Historia gay de Chile" y un estudio ajustado a las convenciones de la disciplina llamada historia. Es cierto que Raro carece de periodificaciones claras, suele no citar sus fuentes ni su bibliografía, o citarlas de forma incompleta. Pero la diferencia más importante entre el texto aquí descrito y un estudio histórico es que Raro no toma en cuenta la historicidad de las propias categorías que utiliza (como sí lo hace todo estudio histórico). Esto se evidencia en las categorías de "sodomita", "homosexual" y "gay"; todas ellas muy utilizadas a lo largo del libro. El autor presenta el origen etimológico de las palabras "sodomita", "homosexual" y "gay", y deja en claro que las tres aparecieron en momentos históricos muy diferentes. "Sodomita" es una palabra muy antigua, mientras que "homosexual" aparece, según el mismo Contardo, en el siglo XIX. El anglicismo gay aparece a comienzos del siglo $X X$, pero solo en la década de 1970 adquiere su significado actual, Sin embargo, en la práctica escritural estas categorías aparecen confundidas y usadas como sinónimos. Esto le resta prolijidad a la exposición y al análisis, y hace menos "historiográfico" el relato.

El libro parte con una revisión de los albores de la criminalización de la sodomía en la Edad Media. Considerada un 
vicio adquirido y contagioso, fue siempre atribuida a un otro. Después del descubrimiento de América, será el indígena quien ocupe este lugar. Ya adentrándose en la Colonia, el autor presenta varios casos de sodomía seguidos contra mestizos, españoles y algunos clérigos. Al final de este período, en el tránsito del siglo XVIII al XIX, la sodomía deja de ser castigada con la muerte. Poco a poco, avanzado el siglo XIX, pasa a ser objeto de atención de la naciente ciencia médica. Esta comenzará a estudiar a los individuos que, con el rótulo de "homosexuales", ya no parecen remitir a un acto (la sodomía) sino a una identidad y un deseo constante por miembros de su mismo género. El autor destaca que el término "homosexual" surgió del activismo militante aparecido en Alemania a fines del siglo XIX. Sin embargo, fue capturado por el discurso médico y criminalístico, como una posibilidad de hablar de esta nueva identidad (el individuo homosexual) fuera del ámbito de la marginalidad y la religión.

Es en este período cuando emerge una subcultura -llamada por Contardo- homosexual en los bares y prostíbulos de Santiago y Valparaíso, en consonancia con las subculturas de las grandes urbes europeas, pero a una escala mucho menor. Así por ejemplo, a comienzos del siglo XX ya existía en Santiago una especie de circuito homosexual en torno al cerro Santa Lucía, la Estación Mapocho y lugares específicos del centro (146). Los puntos de encuentros secretos eran "cantinas de mala muerte, baños públicos, prostíbulos y parques" (157). Asimismo, desde la década de 1940, algunos homosexuales burgueses vivían en el barrio que rodea el cerro Santa Lucía. Ellos formaron parte de cierta sociabilidad homosexual que, a mediados del siglo XX, participaba de todo un sistema de códigos culturales. Allí primaba el travestismo verbal, el levante callejero o cruising, el ejercicio de la ironía y el subtexto como estrategia de defensa. Mientras, gustaban de aventuras con hombres de clase baja, considerados más "hombres".

Contardo se aboca también a contar las peripecias de intelectuales, escritores y artistas homosexuales. Entre ellos, se encuentran Augusto d'Halmar, Hernán Díaz Arrieta, Benjamín Subercaseaux, Luis Oyarzún, Roberto Humeres, Enrique Lafourcade y Rolando Alarcón. 
A contrapelo de estos de la mano del mercado, sin discursos de emergencia cul- reivindicaciones políticas que tural, el siglo XX también pre- fueran a la par del consumo, senció la irrupción de discursos y con una izquierda que higienistas y eugenésicos en el desdeñaba a los homosexuales. seno del aparato estatal. Esto significó que, entre las décadas de 1930 y 1960, la homosexualidad pasara de considerarse un delito a un trastorno médico, del ámbito psíquico o endocrinológico.

El autor luego recala en la homofobia de la prensa de izquierda durante la Unidad Popular. Bajo la dictadura militar, sin embargo, surgió un circuito de lugares abiertamente dirigidos a una clientela homosexual o lésbica. Contardo es hábil en señalar la particularidad del caso chileno en cuanto a la aparición de este circuito: en plena dictadura y

\section{Bibliografía}

Contardo, Óscar. Raro. Una historia gay de Chile. Santiago: Planeta, 2011. 